\title{
Gelişmekte Olan Hisse Senedi Piyasaları İle Kıymetli Madenler Arasındaki Getiri ve Volatilite Yayılımı
}

\section{Return and Volatility Spillover Between Emerging Stock Markets and Precious Metals}

\author{
İsmail ÇELIK' \\ Arife ÖZDEMIR ${ }^{2}$ \\ Samet GÜRSOY ${ }^{3}$ \\ Hande Uzunoğlu ÜNLÜ4
}

$0000-0002-6330-754 X$
$0000-0002-9902-9174$
$0000-0003-1020-7438$
$0000-0002-7719-5163$

\begin{abstract}
ÖZET
$\mathrm{Bu}$ çalışma, portföy çeşitlendirme ve riskten korunma gibi konularda yatıımcıların son dönemde üzerinde yoğunlaştığı kıymetli madenlerle gelişmekte olan ülke borsa endeksleri arasındaki getiri ve volatilite yayılımlarını ortaya koymayı amaçlamaktadır. Çok değişkenli VAR-EGARCH analizi sonucunda kıymetli madenler için negatif bilgi şoklarının daha baskın olduğu tespit edilmiştir. Altın getirilerinden Endonezya, Hindistan, Brezilya ve Türkiye hisse senedi piyasalarına pozitif, Brent petrol getirilerinden ise Hindistan, Brezilya ve Türkiye hisse senedi piyasalarına negatif getiri yayılımı olduğu ayrıca kanıtlanmıştı. Her iki kıymetli madenin de pozitif getiri yayılımı olduğu tek piyasa Güney Afrika piyasası olmuştur. Modelin varyans denklem sonuçlarına göre kıymetli madenlerden Türkiye hisse senedi piyasasına herhangi bir volatilite yayılımı olmadığı bu sebeple diğer ülke piyasaları ile kıyaslandığında Türkiye hisse senedi piyasasının daha güçlü olduğu sonucuna ulaşıımıştır.
\end{abstract}

Anahtar Kelimeler: Getiri ve Volatilite yayılımı, Çok Değişkenli VAR-EGARCH, Kıymetli Madenler

\section{GiRiş}

Ülkeler arasındaki finansal entegrasyonun hem dış ticari ilişkiler hem de portföy yatırımları ile artması bireysel ve kurumsal yatırımcıların portföy çeşitlendirme ve riskten korunma konusunda eskiye nazaran daha hassas olmalarına sebep olmuştur.

Dünya ekonomisinde artan belirsizlikler ve fiyat dalgalanmaları günümüzde daha dikkatli bir risk

\begin{abstract}
This study aims to reveal the return and volatility spillovers between developing/emerging country stock market indexes and precious metals that investors recently have concentrated on issues such as portfolio diversification and hedging. As a result of the multivariate VAR-EGARCH analysis, negative information shocks for precious metals have been found to be more dominant.

It is proved that from gold returns to the equity markets of Indonesia, India, Brazil, Turkey have positive spillover, also from Brent oil returns to the equity markets of India, Brazil, Turkey have negative return spillover. The only market in which both of precious metals have positive return spillover has been the South African market. According to the results of the model's variance equation, there is no volatility spillover to the Turkish equity markets from precious metals therefore the result is that Turkish equity market is stronger compared to other countries' markets.
\end{abstract}

Key Words: Return and Volatility Spillover, Multivariate VAR-EGARCH, Precious Metals

yönetimi uygulamayı zorunlu hale getirmekle birlikte risk yönetiminde kullanılacak türev ürünler hem şirketlerin korunma stratejilerinde hem de piyasaların oynaklığının azaltılması açısından büyük bir önem arz etmektedir (Çevik ve Pekkaya, 2007: 49).

Türev ürünler içerisinde yer alan kıymetli madenlerin dünya genelinde kullanım alanının genişlemesi ve otomasyona dayalı üretimdeki hızlı gelişmeler, 
kıymetli madenlerin fiyatlarındaki değişmelerin hem yatırım ve iş dünyası hem de politika yapıcılar tarafından dikkatle takip edilmesine sebep olmuştur. Altın ve petrol gibi emtia piyasalarının yükselen trendi uluslararası finansal piyasaların artan volatilitesiyle birlikte emtia ve piyasa volatilitesinin incelenmesini gerekli kılmaktadır. Emtia fiyatlarının davranışları ve emtia piyasaları ile hisse senedi piyasaları arasındaki volatilite geçiş mekanizmalarının anlaşılması hükümetler, tüccarlar, portföy yöneticileri ve yatırımcılar açısından oldukça hayati bir öneme sahiptir (Hossenidoust vd., 2013:1401). Özellikle ara malı ithalatına bağımlı bir dış ticaret karakteri gösteren Türkiye gibi gelişmekte olan ülkelerde kıymetli madenlerin fiyatlarındaki değişmeler ödemeler bilançosunda cari işlemler açığının artmasına ve böylelikle de yabancı portföy yatırımcıları için belirsizliğin olduğu bir görünüm sergilemesine de sebep olabilmektedir.

Hisse senedi piyasaları ekonomik, politik ve sosyal gelişmeler gibi birçok faktörden etkilenmektedir. Hisse senedi fiyatı; altın fiyatları, ham petrol fiyatları, altın ve petrol fiyat volatilitesi, enflasyon oranı, döviz oranı dahil olmak üzere birçok makroekonomik değişken tarafından etkilenmektedir (Gokmenoglu ve Fazlollahi, 2015:479). Bu gerekçelerle gerçekleştirilen çalışma ile petrol ve altın gibi iki kıymetli maden fiyatlarındaki değişmelerin gelişmekte olan ülke hisse senedi piyasalarına hem getiri hem de getiri volatilitesi açısından herhangi bir bulaşma ya da karşıııkı geçiş etkisinin olup olmadığı incelenmeye çalışılacaktır. Bu yüzden bu çalışmada emtia ve hisse senedi endeksi arasındaki getiri ve volatilite yayılımı çok değişkenli VAR-EGARCH modeli ile analiz edilmeye çalışılacaktır. Çalışmanın ilerleyen bölümlerinde petrol ve emtia piyasalarına ilişkin yapılan çalışmaları inceleyen literatür bölümü, daha sonra gerçekleştirilecek analize ilişkin metodoloji ve araştırma sonuçları yer alacaktır.

\section{LITERATÜR TARAMASI}

Hammoudeha ve Choi (2007), 15.02.199428.12.2004 dönemine ait verileri kullanarak UC-MS modeli ile GCC hisse senedi piyasaları ve petrol piyasaları arasındaki ilişkiyi incelemiş ve yüksek volatilite olduğunu ortaya koymuştur. Ancak volatilite sürekliliği açısından farklılıklar gözlenmiştir. S. Arabistan ve Umman en yüksek volatiliteye sahip ülke olurken petrol ihraç eden kriz içindeki Meksika da diğer tüm GCC ülkelerinden daha fazla volatilite gözlenmiştir.

Büyükşahin vd. (2008), 02.01.1991-26.05.2008 tarihleri arası verileri kullanarak çeşitli emtia ve hisse senetleri arasındaki etkileşimi dinamik korelasyon, eş bütünleşme tekniklerini kullanarak analiz etmiş ve çeşitli emtialara yatırım yapılmasının hisse senedi getirilerine etkisinin olmadığını yani öz kaynaklarda artışa neden olmadığını kanıtlamıştır.

Soytaş vd. (2009), dünya petrol fiyatı, Türk faiz oranı, Türk lirası-Amerikan doları döviz kuru oranı, yerli spot altın ve gümüş fiyatı arasındaki kısa ve uzun dönemli bilgi iletimini 02.05.2003-01.03.2007 arası verileri kullanarak VAR ve Granger Nedensellik analizleri ile incelemişlerdir. Analiz sonucunda dünya petrol fiyatlarının Türkiye'deki kıymetli metal fiyatları, döviz kuru oranı ve faiz oranı üzerinde hiçbir tahmin gücü olmadığı ortaya çıkmıştır. Sonuçlar aynı zamanda altının Türk Lirası́nın devalüasyon döneminde güvenli bir cennet olduğunu göstermiştir.

Bhar ve Nikolova (2010), Ocak 1995-Şubat 2007 yılları arası haftalık verileri kullanarak petrol fiyat değişikliklerinin Rusya'da sermaye yatırımları üzerindeki etkisini EGARCH yöntemi ile analiz etmiştir. Yapılan analiz sonucunda küresel petrol fiyatlarının Rusya sermaye piyasaları üzerinde önemli etkisinin olduğu ortaya çıkmıştır.

Sari vd. (2010), dört değerli metalin spot fiyatları (altın, gümüş, platin, palladyum), petrol fiyatları ve ABD doları/euro döviz kuru arasındaki eş hareketliliği ve bilgi geçişlerini 04.01.1999-19.10.2007 arası verileri kullanarak Johansen Eşbütünleşme testi ve VAR analizi ile incelemişlerdir. Analiz sonucunda uzun dönemli denge ilişkisinin zayıf olduğu; ancak kısa dönemde geri beslemelerin güçlü olduğu ortaya çıkmıştır. Spot kıymetli maden piyasası döviz kuru ve diğer metal fiyatlarındaki şoklara cevap vermektedir. Döviz kuru piyasasının yanı sıra platin ve palladyum piyasasının da aşırı reaksiyon gösterdiğine dair de kanıtlar bulunmuştur.

Palakkod (2012), Hindistan'da sermaye piyasası, döviz piyasası ve emtia piyasası arasındaki volatilite yayılımına yönelik karşılıklı ilişkiyi 06.06.200531.03.2010 arası verileri kullanarak AR(1)-GARCH $(1,1)$ modeli ile incelemiştir. Yapılan analiz sonucunda döviz piyasaları ve emtia piyasalarından sermaye piyasalarına doğru ve sermaye piyasalarından döviz piyasasına doğru volatilite yayılımı olduğu tespit edilmiş emtia piyasalarından döviz piyasasına doğru bir yayılım gözlenmemiş bunun yanı sıra emtia piyasalarında volatilite yayılımına yönelik bir kanıta ulaşılmamıştır.

Brooks ve Prokopczuky (2013), Ocak 1985-Mart 2010 arası verileri kullanarak ABD'deki altı önemli em- 
tia piyasası arasındaki fiyat ve volatilite ilişkisi Bayesian Markov Chain Monte Carlo modeli ile analiz edilmiş ve hisse senedi piyasası özellikleri ile karşılaştırılmıştır. Analiz sonucunda hem emtia ve borsa endeksi arasındaki getiri korelasyonunun düşük olduğu hem de emtia ve borsa arasındaki volatilitenin düşük olduğu gözlenmiş bunun sonucunda emtiaların portföy çeşitlendirmede kullanılabilecek önemli bir araç olduğu ortaya çıkmıştır.

Chang vd. (2013), 02.01.1998-04.11.2009 yılları arası ham petrol getirileri ve hisse senedi endeks getirileri arasındaki volatilite yayılımı ve yüksek korelasyonu CCC, VARMA-GARCH, VARMA-AGARCH ve DCC modelleri yardımıyla araştırmıştır. CCC model sonuçları koşullu şokların sadece aynı piyasalarda etkili olduğunu karşı piyasalarda etkili olmadığını ortaya koyarken, DCC model sonuçları ise koşullu şokların her zaman önemli olduğu sonucunu ortaya çıkarmıştır. VARMA-GARCH, VARMA-AGARCH modelleri ham petrol ve finansal piyasalar arasında volatilite yayılımı olduğuna dair kanıtlar sunmaktadır. Koşullu varyansdaki eşit büyüklükte negatif ve pozitif şokların asimetrik etkileri VARMA-AGARCH modelinin VARMA-GARCH ve CCC modelinden daha üstün olduğunu göstermektedir.

Ciner (2013), petrol fiyatlarındaki değişiklikler ile hisse senedi getirileri arasındaki ilişkiyi Ocak 19986-Aralık 2010 dönemi verileri kullanarak frekans bölge regresyonu modeli ile incelemiştir. Petrol ve hisse senetleri arasındaki bağlantıda önemli zaman değişimi bulunmuştur. Analiz petrol fiyat hareketlerinin hepsinin aynı olmadığını, petrol ve borsadaki müşterek artışların gözlemlenebileceğini desteklemektedir.

Ewing ve Malik (2013), 01.07.1993-30.06.2010 arası günlük getiriyi kullanarak yapısal kırılmaları içeren vadeli altın ve petrol değişkenlerinin volatilitesini incelemek için tek değişkenli ve iki değişkenli GARCH modellerini kullanmışlardır. Modelde varyansa bağı yapısal kırılmalar hesaba katıldığında altın ve petrol getirileri arasında volatilite geçişlerine dair güçlü kanıtlar bulunmuştur.

Hosssenidoust vd. (2013), Ocak 2000-Ocak 2013 dönemi arası aylık veriler kullanarak yaptıkları çalışmada ASEAN-5 hisse senedi getiri volatilitesi üzerine petrol ve altın fiyatları volatilitesinin yayılım etkisini EGARCH, MEGARCH modelleri ile incelemişlerdir. Petrol fiyatları tüm hisse senedi piyasa endekslerinde pozitif ve anlamlı bir etkiye neden olmakta bu da petrol fiyatlarındaki herhangi bir artışın piyasa getiri endekslerinde artışa yol açacağını göstermektedir. Bunun yanında altının Endonezya, Filipinler ve Tayland'da iyi çeşitlendirilmiş bir portföy için güvenli bir liman olduğu tespit edilmiştir.

Mensi vd. (2013), yaptıkları çalışmalarında 2000-2011 dönemi için S\&P 500 ve enerji, gıda, altın endeksleri, içkiler arasındaki getiri bağlantıları ve volatilite iletimini VAR-GARCH modelini kullanarak incelemişlerdir. Yaptıkları inceleme sonucunda S\&P 500 ve emtia piyasaları arasında önemli geçişler olduğu sonucuna varmışlardır.

Sadorsky (2014), 03.01.2000-29.06.2012 yılları arası verileri kullanarak VARMA-AGARCH, DCC-AGAR$\mathrm{CH}$ modelleri ile gelişmekte olan piyasalardaki hisse senedi, petrol, bakır ve buğday fiyatları arasındaki volatilite ve koşullu korelasyon ilişkisini incelemiştir. Analiz sonucunda gelişmekte olan piyasa hisse senedi fiyatları ve petrol fiyatlarının her biri pozitif kaldıraç etkisi göstermekte; gelişmekte olan piyasa hisse senetleri, petrol, bakır ve buğday fiyatları arasındaki dinamik koşullu korelasyon 2008'den sonra artmakta ve bu durum bu varlıklar arasında çeşitlendirme faydalarının azaldığını göstermektedir.

Sattary vd. (2014), 02.01.2002-31.12.2012 tarihleri arasında petrol piyasası ve BIST 100'de işlem gören enerji, metal dışı mineral ürünlerin imalatı ve ulaşım alt sektörleri arasında volatilite yayılımı olup olmadığını iki değişkenli GARCH $(1,1)$ modelini kullanarak araştırmışlardır. Araştırma sonuçları, metal dışı mineral ürün sektörü hariç, petrol getirileri ve alt sektörler arasında getiri şokları ve koşullu varyans açısından etkileşim olduğunu göstermiştir.

Uludağ ve Lkhamazhapov (2014), yaptıkları çalışmada Türkiye'de spot ve vadeli altın getiri ve volatilitesinde yapısal kırılma ve uzun hafıza özelliklerini ARFIMA-FIGARCH modeli ile 27.06.2008-31.05.2013 arası dönem için analiz etmişlerdir. ARFIMA-FIGARCH modeli spot serilerinde çifte uzun hafızaya ve vadeli getirilerde uzun hafıza varlığının eksik olduğuna dair kanıtlar bulunmuştur. Geçici spot getirilerde, altın fiyatlarının yeni bilgilere aşırı tepki vermesinin bir göstergesidir ve böylece zayıf piyasa etkinliğini yitirmektedir. Bulgular ayrıca, küresel finansal krizler sonrasında altın fiyatlarında düzeltme ile bağlantılı olan bir yapısal kırılmanın kanıtını ortaya koymaktadır.

Arouri vd. (2015), Çin hisse senedi piyasası ve dünya altın fiyatları arasındaki getiri ve volatilite yayılımını 22.03.2004-31.03.2011 arası verileri kullanarak 
VAR-GARCH ve GARCH tipi modelleri kullanarak incelemişlerdir. İnceleme sonucunda Çin'de altın fiyatları ve hisse senedi fiyatları arasında getiri ve volatilitenin çapraz etkisi olduğuna dair önemli kanıtlar bulunmuş ayrıca VAR-GARCH modelinin diğer çok değişkenli GARCH modellerine nazaran daha iyi sonuçlar verdiği belirlenmiştir. Geçmiş altın getirilerinin Çin hisse senedi piyasalarında koşullu getiri ve volatilitenin açıklanmasında önemli bir rol oynadığı gözlemlenmiştir.

Batten vd. (2015), 1982-2003 arası veriler ile Diebold ve Yılmaz'ın (2009) metodolojisini kullanarak dört ana değerli metal arasındaki bulaşıcılık ve yüzey zaman değişen yayılımları incelemişlerdir. Analiz sonucunda zayıf ilişki olduğu ve bu entegrasyon derecesinin zamanla değişmekte, getiri ve volatilite arasında farklılaştığı görülmektedir.

Mensi vd. (2015), WTI petrol, altın, gümüş, buğday, mısır, pirinç gibi büyük emtia vadeli piyasaları ile büyük bir petrol tabanlı sınır ötesi borsanın zamanla değişen ilişkileri portföy risk yönetimi için yapısal kırılmalı ve yapısal kırılma olmayan iki değişkenli DCC-FIAPARCH modeli ile 01.01.2005-13.08.2014 dönemi için incelemişlerdir. Koşullu volatilitede asimetri ve uzun hafızaya dair sonuçlar bulunmuş aynı zamanda emtialar ile Gümüş-Tadawul çifti hariç Suudi hisse senedi piyasaları arasında önemsiz dinamik koşullu korelasyon olduğu gözlenmiştir. Dahası karışık emtia-hisse senedi portföyleri değerlendirilmiş, çeşitlendirmenin yararlarına, riskten korunma etkinliğine ve olumsuz riskin azaldığına dair güçlü kanıtlar bulunmuştur.

Basher ve Sadorsky (2016), gelişmekte olan hisse senedi piyasa fiyatları, petrol fiyatları, VIX, altın fiyatları ve tahvil fiyatları arasındaki koşullu korelasyon ve volatiliteyi 04.01.2000-31.07.2014 arası verileri kullanarak DCC, ADCC ve GO-GARCH modelleri ile incelemişlerdir. Analiz sonucunda petrolün gelişmekte olan piyasa hisse senedi fiyatlarını korumak için en iyi varlık olduğu ortaya çıkmıştır. Petrol, VIX, tahvil ile gelişmekte olan hisse senedi piyasa fiyatlarının korunması için ADCC modelinden korunma oranları tercih edilmesi gerektiği görülmüştür. GO-GARCH modelinden tahmin edilen korunma oranları altın içeren bazı durumlarda gelişmekte olan hisse senedi piyasa fiyatlarının korunması için daha etkili olduğu görülmüştür.

Bouri vd. (2017), dinamik koşullu korelasyon modelleri ile Bitcoin'in büyük dünya hisse senedi endeksleri, tahvil, petrol, altın, genel emtia endeksi ve $A B D$ doları endeksi için koruyucu ve güvenli bir cennet gibi davranıp davranamayacağı 18.07.201122.12.2015 verileri kullanılarak incelemişlerdir. Sonuçlar Bitcoin'in zayıf bir korunma oranı sağladığını sadece çeşitlendirme amacıyla kullanılabileceğini göstermiştir. Ancak Bitcoin'in Asya Hisse Senedi'nin haftalık aşırı hareketlerine karşı yalnızca güçlü bir cennet olarak hizmet edebileceği de görülmüştür.

Boubaker ve Raza (2017), petrol fiyatları ve BRICS hisse senedi fiyatları arasındaki volatilite ve şokların yayılım etkisini farklı zaman dilimlerinde çok değişkenli yaklaşım ve Wavelet analizini kullanarak 04.01.2000-25.03.2015 dönemi için incelemişlerdir. Sonuçlar, çalışılan tüm pazarlarda zamanla değişen volatilitenin güçlü kanıtlarını ortaya koymaktadır. Ortalama ve oynaklığın yayılma etkileri, heterojen yatırımcılar ve piyasa katılımcısına göre farklı zaman ölçeklerinde birçok alt yayılmaya dönüştüğü görülmüştür.

\section{ARAŞTIRMANIN DIZAYNI}

\subsection{Araştırmanın Amacı}

Çalışmada gelişmekte olan ülkelerin kendi aralarında ve kıymetli madenlerle söz konusu ülkelerin hisse senedi endeksleri arasında getiri ve volatilite geçişlerinin olup olmadığı tespiti amaçlanmıştır.

Getiri ve volatilite yayılımının ölçülmesinde Koutmos (1996) tarafından gelişmiş dört ülke üzerinde uygulanan VAR-EGARCH modeli kullanılmıştır. Modelin VAR analizi kısmı söz konusu piyasalar arasındaki getiri etkileşimini tespit etmekte kullanılmakta EGAR$\mathrm{CH}$ analizinin yapıldığı kısım ise VAR modelinden elde edilen hata terimlerini kullanarak piyasalar arasındaki volatilite yayılımını ortaya koymaktadır.

\subsection{Araştırmanın Metodolojisi}

Araştırma konusu yapılan finansal zaman serileri ile alakalı kurulacak modellerde spesifikasyon problemlerinin yaşanmaması için aşağıda bahsedilen yöntemler sırasıyla veri setine uygulanacaktır.

\subsubsection{Durağanlık Analizi ve Birim kök Testleri}

Modellerin analizleri yapılmadan önce serilerin durağan olup olmadıklarının araştırılması gerekmektedir.

Bir zaman serisinin, varyans ve ortalamasının zaman içinde sabit kaldığı ve kovaryanslarının sadece iki zaman periyodu arasındaki farka bağlı olup, hesaplandığı döneme bağlı olmadığı süreç durağan olarak 
tanımlanmaktadır (Gujarati ve Porter, 2012: 740). Ancak finansal zaman serilerinin genelde durağan olmadığı görülmüştür. Granger ve Newbold (1974), durağan olmayan seriler kullanılarak çalışılması durumunda yüksek (determinasyon katsayısı) ve düşük Durbin Watson değerlerinin yanıltıcı olacağını diğer bir deyişle bu durumun sahte regresyona yol açacağını ortaya çıkarmışlardır. Bu yüzden analizlerin istatistiksel olarak anlamlı olması için serilerin durağan hale getirilmesi gerekmektedir.

Serilerin durağanlığının belirlenmesi için farklı metotlar arasından en çok tercih edilen Genişletilmiş Dickey-Fuller (ADF) ve Philips-Perron (PP) birim kök testleri çalışmada kullanılmaktadır.

Dickey ve Fuller (1979), AR(1) yani birinci dereceden otoregresif süreç denkleminin tahminlemesinden yola çıkarak Dickey-Fuller (DF) birim kök testini ileri sürmüştür.

Sabit terim yok: $\Delta Y_{t}=\delta Y_{t-1}+\varepsilon_{t}$

Sabit terim var: $\Delta Y_{t}=\beta_{0}+\delta Y_{t-1}+\varepsilon_{t}$

Sabit terim ve trend var:

$$
\Delta Y_{t}=\beta_{1}+\beta_{2} t+\delta Y_{t-1}+\varepsilon_{t}
$$

Dickey ve Fuller (1981), bağımlı değişkenin gecikmeli değerlerini, Dickey-Fuller denklemine dahil edilerek hata terimleri arasındaki otokorelasyonu giderecek Genişletilmiş Dickey-Fuller (ADF) birim kök testini modellemiştir.

$$
\Delta Y_{t}=\beta_{1}+\beta_{2} t+\delta Y_{t-1}+\sum_{n=1}^{p} \alpha_{t} \Delta Y_{t-1}+\varepsilon_{t} 4 .
$$

Temel hipotez, $H_{0}: \delta=0$ ve alternatif hipotez ise, $H_{1}: \delta<0$ olarak kurulur. Burada $H_{0}$ hipotezi birim kök olduğunu yani serinin durağan olmadığını hipotezi ise, serinin durağan olduğunu belirtmektedir. $\delta$ katsayısının, ADF testi ile istatistiksel olarak sıfır olup olmadığı sınanırken, ADF-t istatistiğinin MacKinnon (1991) kritik değerleri ile karşılaştırılarak ADF-t istatistiğinin MacKinnon kritik değerinden mutlak değerce büyük olması aranmaktadır. Böylece serinin durağan olduğu söylenebilir aksi halde seri durağan oluncaya kadar farkının alınması gerekmektedir.

Diğer taraftan, hata terimlerinin istatistiksel olarak bağımsız olduğu, sabit varyansa sahip olduğu ve de normal dağılım gösterdiği varsayımlarının sağlanmadığı durumlar ortaya çıkmıştır. Bu durumlarda, Genişletilmiş Dickey-Fuller modeli yetersiz kaldığından dolayı Phillips-Perron modeli önerilmiştir. Phillips ve Perron (1988), Dickey-Fuller modelini geliştirerek hata terimlerinde oluşabilecek ardışık ilişkiyi (otokorelasyonu) ortadan kaldırmak için gecikmeli fark değerlerini ilave etmek yerine nonparametrik istatistiksel yöntemler kullanmıştır (Gujarati ve Porter, 2012:758). Böylece Phillips-Perron testi hata terimlerinin zayıf bağımlı şekilde dağılım göstermesine izin vererek test istatistiklerinin daha az sınılayıcı hata sürecine sahip olmasını sağlamaktadır (Yavuz, 2015:304).

Phillips-Perron testinde ADF testi ile ayn asimtotik dağılıma sahip test istatistiği olduğundan, test istatistiği MacKinnon kritik değerleri ile karşılaştırılmaktadır. Phillips-Perron birim kök test hipotezi de ADF testi ile aynı şekilde kurulmaktadır.

\subsection{2. Çok Değișkenli VAR-EGARCH Modeli}

Çalışmada uygulanan çok değişkenli VAR-EGAR$\mathrm{CH}$ modelini açıklamadan önce tek değişkenli ARCH ve $\mathrm{GARCH}$ modelinden bahsedilmiş daha sonrada EGARCH modeli üzerinde durulmuştur.

Klasik zaman serilerinde, tahmin edilen modelin hata terimi varyansının zamana bağlı olarak sabit kalması temel varsayımlardan biridir. Bu durum homoskedastisite (homoscedasticity) olarak tanımlanmaktadır (Tarı,2010:24). Ancak, finansal zaman serileriyle yapılan tahminlemelerde hata terimi varyansının sabit kalmadığı yani genellikle zamana bağlı olarak değişebildiği (heteroskedasticity) ortaya konulmuştur. Bu bağlamda, Engle (1982) yaptığı çalışma sonucunda koşullu varyansın, hata terimlerinin gecikmeli değerlerinin karelerine bağlı olarak değişmesini mümkün kılan otoregresif koşullu değişen varyans (Autoregressive Conditional Heteroscedasticity-ARCH) modelini ileri sürmüştür.

$$
\sigma_{t}^{2}=\alpha_{0}+\alpha_{1} \varepsilon_{t-1}^{2}+\cdots+\alpha_{q} \varepsilon_{t-q}^{2}
$$

ARCH modelinin uygulanması sırasında, nisbi olarak uzun gecikmeler kullanılması, sabit gecikme yapısının önerilmesi ve negatif varyanslı parametre tahminlerinden kaçınılması nedeniyle koşullu varyans denklemindeki parametrelere kısıtlar getirilmiştir. $\mathrm{Bu}$ kısıtların gerçekleşmemesi sonucunda ortaya çıkan sorunların önüne geçmek amacıyla Bollerslev (1986) genelleştirilmiş otoregresif koşullu değişen varyans (Generalized Autoregressive Conditional Heteroskedasticity - GARCH) modelini önermiştir. GARCH $(p, q)$ süreci denklem ile gösterilmiştir:

$$
\sigma_{\mathrm{t}}^{2}=\alpha_{0}+\sum_{\mathrm{i}=1}^{\mathrm{p}} \alpha_{\mathrm{i}} \varepsilon_{t-i}^{2}+\sum_{\mathrm{j}=1}^{\mathrm{q}} \beta_{\mathrm{j}} \sigma_{\mathrm{t}-\mathrm{j}}^{2}
$$


GARCH $(p, q)$ modelinde, hem ARCH modelinde kullanılan hata terimlerinin gecikmeli değerlerinin karelerine $\left(\varepsilon_{t-1}^{2}, \varepsilon_{t-2}^{2}, . ., \varepsilon_{t-p}^{2}\right)$ hem de koşullu varyans terimlerinin gecikmeli değerlerine $\left(\sigma_{t-1}^{2}, \sigma_{t-2}^{2}, \ldots, \sigma_{t-q}^{2}\right)$ yer verilmektedir. GARCH modeli daha fazla geçmiş bilgilere dayanmakta olup esnek bir gecikme yapısına da olanak sağlamaktadır (Bollerslev, 1986:308).

$A R C H$ ve GARCH modellerinde, volatilite üzerindeki negatif (olumsuz) bir şok ile pozitif (olumlu) bir şok aynı etkiye sahip olmaktadır (Nelson, 1991: 349, Tsay, 2002: 95). Başka bir ifadeyle, şokların volatilite üzerinde simetrik etki yarattığı varsayılmaktadır. Diğer taraftan şokların volatilite üzerinde asimetrik etki yarattığı durumlar da ortaya çıkabildiği için Nelson (1991), volatilite üzerindeki asimetriyi dikkate alarak Üssel GARCH (EGARCH) modelini önermiştir. Koşullu varyansın, gecikmeli hata terimlerinin hem büyüklüklerini hem de işaretlerini dâhil eden EGARCH modelinin denklemi,

$$
\begin{aligned}
& \log \sigma_{\mathrm{t}}^{2}=\alpha_{0}+\sum_{t=i}^{p} \beta_{i} \log \sigma_{t-i}^{2}+ \\
& \sum_{t=i}^{q} \gamma_{i} \frac{\varepsilon_{t-i}}{\sigma_{t-i}}+\sum_{t=i}^{q} \alpha_{i}\left|\frac{\varepsilon_{t-i}}{\sigma_{t-i}}\right|
\end{aligned}
$$

olarak tanımlanmıştır.

Denklemde, ARCH etkisi olarak tanımlanan $\alpha$ parametresi büyüklük etkisini gösterirken $\beta$ parametresi ise volatilite kalıcılığını ifade etmektedir. Asimetrik etkiyi ölçen $\gamma$ parametresinin negatif olması, negatif şokların pozitif şoklara göre volatilite üzerinde daha fazla etkiye sahip olduğunu göstermektedir (Engle ve $\mathrm{Ng}, 2003:$ 1752). Ayrica parametreler negatif olsa bile logaritmik dönüşüm yapıldığından dolayı koşullu varyans pozitif olacaktır.

Koutmos ve Booth (1995), Nelson (1991)'un tek değişkenli olarak önerdiği EGARCH modelini çok değişkenli model olarak genişletmiştir. Daha sonra Koutmos (1996) çok değişkenli VAR- EGARCH modelini ileri sürmüştür.

$$
R_{i t}=\beta_{i, 0}+\sum_{j=1}^{N} \beta_{i, j} \mathrm{R}_{j, t-1}+\varepsilon_{i, t}
$$

Her bir piyasanın koşullu ortalaması, kendi gecikmeli getirileri ve aynı zamanda çapraz piyasa gecikmeli getirilerinin bir fonksiyonu olan ve $\mathrm{N}$ tane piyasanın getirilerini ele alan VAR modeli 8. denklemde gösterilmiştir. Denklemde $\mathrm{i} \neq \mathrm{j}$ olmak üzere, $\beta_{i, j}$ öncül-ardıl ilişkisini belirtmektedir. $\beta_{i, j}$ katsayısı anlamlı olduğunda, j piyasasının geçmiş getirileri i piyasasının mevcut getirilerini tahmin etmek için kullanılabilmektedir (Koutmos, 1996:977).

Piyasaların kendi geçmiş şokları ile çapraz piyasa standardize edilmiş şoklarının üssel fonksiyonu olan koşullu varyans denklemi de aşağıdaki gibidir:

$$
\begin{aligned}
& \sigma_{i, \mathrm{t}}^{2}=\exp \left\{\alpha_{i, 0}+\sum_{j=1}^{N} \alpha_{i, j} f_{j}\left(z_{j, t-1}\right)+\right. \\
& \left.\gamma_{i} \ln \left(\sigma_{i, t-1}^{2}\right)\right\}
\end{aligned}
$$

$\mathrm{i} \neq \mathrm{j}$ olmak üzere $\alpha_{i, j}$ piyasalar arasındaki volatilite ilişkisini gösterirken $\gamma_{i}$ ise i piyasasının volatilitedeki kalıcılığını işaret etmektedir.

$$
\begin{aligned}
& f_{j}\left(z_{j, t-1}\right)=\left(\left|z_{j, t-1}\right|-E\left|z_{j, t-1}\right|\right)+\delta_{j} z_{j, t-1} \\
& \sigma_{i, j, t}=\rho_{i, j} \sigma_{i, t} \sigma_{j, t}, \mathrm{i}, \mathrm{j}=1,2,3, . ., \mathrm{N} \text { ve } \mathrm{i} \neq \mathrm{j}
\end{aligned}
$$

Standardize edilmiş gecikmeli şokların asimetrik fonksiyonunu gösteren 10. denklemde fonksiyonun eğimi, $Z_{j, t-1}<0$ için $\left(-1+\delta_{j}\right)^{\prime}$ ye diğer taraftan, $Z_{j, t-1}$ $>0$ için $\left(1+\delta_{j}\right)^{\prime}$ ye eşit olmaktadır. Böylece piyasaların gecikmeli şokları ve çapraz piyasa şoklarının, piyasaların koşullu varyansları üzerinde asimetrik etki yaratacağı anlamına gelmektedir. $\left|z_{j, t-1}\right|-E\left|z_{j, t-1}\right|$ terimi büyüklük etkisini, $\delta_{j} z_{j, t-1}$ terimi ise işaret etkisini ölçmektedir. $\delta_{j}$ katsayısının negatif olması ile $\alpha_{i, j}$ katsayısının pozitif ve anlamlı olması birlikte değerlendirildiğinde, negatif şokların pozitif şoklara göre volatilite üzerinde daha fazla etkisi olmaktadır. Bu durum volatilite yayılım mekanizmasının asimetrik olduğunu göstermektedir. Piyasa getirileri arasındaki eşzamanlı ilişkiyi ortaya koyan koşullu kovaryansı tanımlayan 11. denklem ise, i ve j pazarlarının getirilerinin korelasyonunun sabit olduğunu belirtmektedir (Koutmos, 1996: 977-978). Normal dağılım ve T gözlem sayısı varsayımı altında, çok değişkenli VAR-EGARCH modeli için log olasılığı fonksiyonu aşağıdaki şekliyle ifade edilmiştir:

$$
\begin{aligned}
& \mathrm{L}(\Theta)=-0.5(N T)^{\ln 2 \pi-0.5} \\
& \sum_{t=1}^{T}\left(\ln \left|S_{t}\right|+\varepsilon_{t} S_{t}^{-1} \varepsilon_{t}\right)
\end{aligned}
$$

$\mathrm{N}$ denklemlerin sayısını (örneğin kullanılan dört değişken için $N=4), \Theta$ tahmin edilecek parametre vektörünü, $\varepsilon_{t}$ t zamandaki şokların vektörünü, $S_{t}$ ise zaman ile değişen koşullu varyans- kovaryans matrisini göstermektedir (Koutmos, 1996: 978).

\subsection{Veri Seti}

Çalışmada altın ve ham petrol getirileri ile seçilmiş gelişmekte olan ülke borsaları arasındaki getiri ve volatilite yayılımlarının incelenmesi amacıyla Türkiye 
için BIST 100 endeksi, Brezilya için BOVESPA endeksi, Hindistan için BSESN endeksi, Endonezya için JKSE endeksi ve Güney Afrika için de INVSAF 40 endeksi baz alınmıştır. Ham petrol fiyatları için de Brent Petrol serisinden faydalanılmıştır. Söz konusu 5 ülkenin seçilmesinde özellikle Morgan Stanley'in 2013 ağustosunda hazırlamış olduğu kırılgan beşli raporu etkili olmuştur. ABD doları karşısında söz konusu ülkelerin ulusal paralarının değer kaybı ve makroekonomik göstergeler açısından bu ülkelerin benzer özelliğe sahip olması çalışmanın örnekleminde dikkate alınmalarına sebep olmuştur.

Araştırmada 01.02.2006-30.07.2015 periyodu içerisindeki gün sonu verilerden faydalanılmış farklı tatil günleri olan ülkelerle çalışıldığı için veri senkronizasyonuna gidilmiştir. Borsaların işlem görmediği günlerde en son kapanış fiyatları dikkate alınmıştır. Söz konusu veri setlerine yahoo finance, investing. com ve borsaların web sitelerinden ulaşılmıştır. Araştırmadaki veri seti dönemine 2008-2009 kriz dönemi de dahildir; ancak çalışmada kriz öncesi ve sonrası dönem için ayrı ayrı volatilite yayılımına bakılmamıştır. Çünkü yapısal kırılmayı dikkate alan çalışmalarda genellikle tek değişken veya iki değişkenli GARCH modelleri kullanılarak sadece volatilite yayılımları incelenmişken bu çalışmada getiri ve volatilite çok değişkenli VAR-EGARCH modeli ile incelenmiştir.

\subsection{Araştırma Bulguları}

Fiyat serileri ile gerçekleştirilecek analizlerde durağanlık sorununun olmasındaki sakıncalardan kurtulmak için öncelikle fiyat serilerinden logaritmik getiriler elde edilmiş ve aşağıdaki logaritmik getiri formülü kullanılmıştır.

$$
\ln \left(P_{t} / P_{t-1}\right)
$$

Şekil 1: GOLD, BRENT, BIST 100, BOVESPA, BSESN, JKSE, INVSAF 40 Fiyat Seri Grafikleri
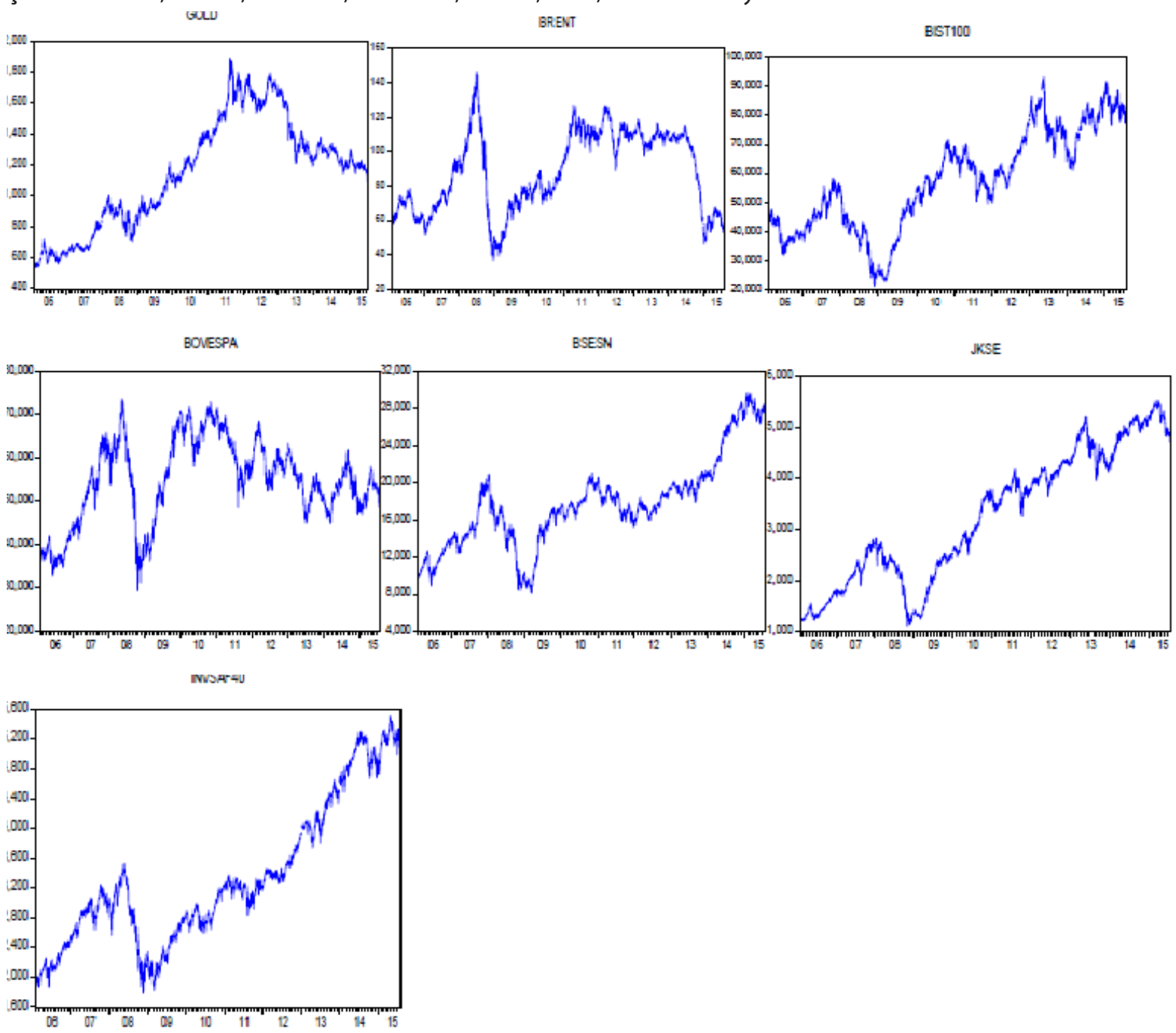
Şekil 2: GOLD, BRENT, BIST 100, BOVESPA, BSESN, JKSE, INVSAF 40 Getiri Seri Grafikleri
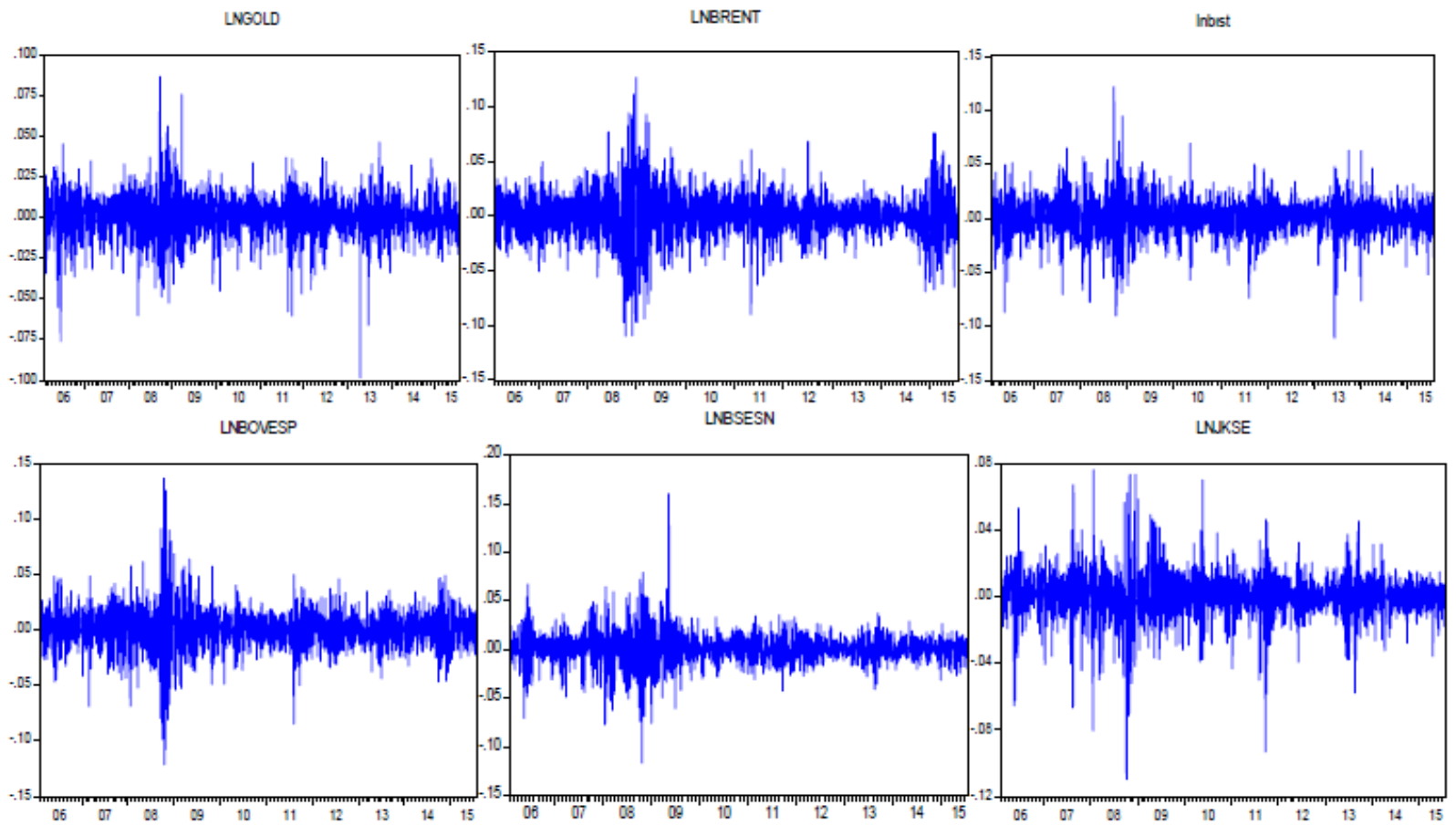

Innvsf

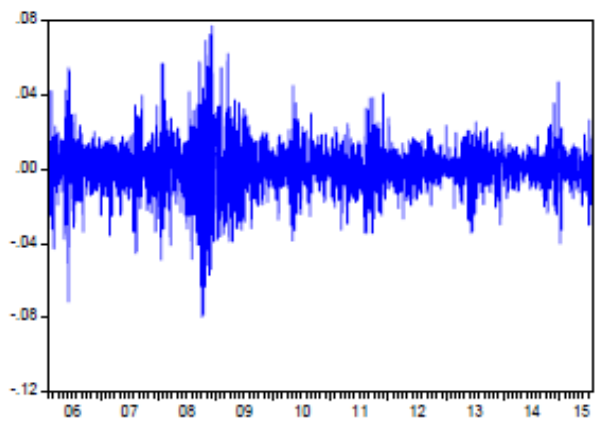

Fiyat ve logaritmik getiri grafikleri incelendiğinde kriz döneminde getiriler üzerinde ciddi volatilite artışlarının olduğu görülmektedir. Fiyat ve getiri serileri için gerçekleştirilen hem sabitli hem de sabitli/trend'li birim kök testi sonuçlarına göre getiri serilerinin sabit bir ortalama etrafında dağıldığı yani birim kök içermediği test istatistiklerinin mutlak değerce MacKinnon kritik değerlerinden büyüklüğünden anlaşılmaktadır.
Zaman serilerinde değişen varyans sonunun olduğu durumlarda koşullu değişen varyans modellerinin kurulması gerekmektedir. Çok değişkenli VAR-EGARCH modelinin tahmin edilmesinde önce uygun gecikme uzunluğunun tespiti araştırılmış ve SC bilgi kriterine göre en uygun gecikme uzunluğu 2 olarak bulunmuştur. 
Tablo 1: Birim Kök Test Tablosu

\begin{tabular}{|c|c|c|c|c|c|c|}
\hline & & \multicolumn{2}{|c|}{ Fiyat Serisi } & \multicolumn{3}{|c|}{ Getiri Serisi } \\
\hline & & ADF & PP & & ADF & PP \\
\hline \multirow[t]{2}{*}{ GOLD } & $\mathrm{S}$ & $-1,666036$ & $-1,654430$ & \multicolumn{2}{|c|}{$-14,40200^{*}$} & $-49,17963^{*}$ \\
\hline & $\mathrm{S} / \mathrm{T}$ & $-0,771931$ & $-0,682782$ & \multicolumn{2}{|c|}{$-14,55936^{*}$} & $-49,25852^{*}$ \\
\hline \multirow[t]{2}{*}{ BRENT } & $\mathrm{S}$ & $-1,568880$ & $-1,555100$ & \multicolumn{2}{|c|}{$-10,13384^{*}$} & $-52,77948^{*}$ \\
\hline & $\mathrm{S} / \mathrm{T}$ & $-1,136119$ & $-1,141117$ & \multicolumn{2}{|c|}{$-10,20584^{*}$} & $-52,81436^{*}$ \\
\hline \multirow[t]{2}{*}{ XU100 } & $\mathrm{S}$ & $-1,178958$ & $-1,205024$ & \multicolumn{2}{|c|}{$-48,93658^{*}$} & $-48,93487^{*}$ \\
\hline & $\mathrm{S} / \mathrm{T}$ & $-2,793729$ & $-2,840965$ & \multicolumn{2}{|c|}{$-48,92888^{*}$} & $-48,92707^{*}$ \\
\hline \multirow[t]{2}{*}{ BOVESPA } & $\mathrm{S}$ & $-2,501923$ & $-2,441688$ & \multicolumn{2}{|c|}{$-8,529375^{*}$} & $-51,42456^{*}$ \\
\hline & $\mathrm{S} / \mathrm{T}$ & $-2,335106$ & $-2,283692$ & \multicolumn{2}{|c|}{$-8,586062^{*}$} & $-51,43959^{*}$ \\
\hline \multirow[t]{2}{*}{ BSESN } & $\mathrm{S}$ & $-79,1850$ & $-0,904775$ & \multicolumn{2}{|c|}{$-12,93889^{*}$} & $-46,84301^{*}$ \\
\hline & $\mathrm{S} / \mathrm{T}$ & $-1,942366$ & $-2,085517$ & \multicolumn{2}{|c|}{$-12,93682^{*}$} & $-46,84301^{*}$ \\
\hline \multirow[t]{2}{*}{ JKSE } & $\mathrm{S}$ & $-1,141932$ & $-1,144493$ & \multicolumn{2}{|c|}{$-12,53577^{*}$} & $-44,50279^{*}$ \\
\hline & $\mathrm{S} / \mathrm{T}$ & $-2,020860$ & $-2,111038$ & \multicolumn{2}{|c|}{$-12,57408^{*}$} & $-44,50519^{*}$ \\
\hline \multirow[t]{2}{*}{ INVSAF40 } & $\mathrm{S}$ & $-0,416529$ & $-0,341106$ & \multicolumn{2}{|c|}{$-11,81433^{*}$} & $-50,26586^{*}$ \\
\hline & $\mathrm{S} / \mathrm{T}$ & $-1,752122$ & $-1,865153$ & \multicolumn{2}{|c|}{$-11,81191^{*}$} & $-50,25358^{*}$ \\
\hline & & \multirow{4}{*}{ MacKinnon p-değeri } & & Sabitli & \multicolumn{2}{|l|}{ Sabitli-Trendli } \\
\hline & & & $\% 1$ & -3.432828 & \multicolumn{2}{|l|}{-3.961795} \\
\hline & & & $\% 5$ & -2.862521 & \multicolumn{2}{|l|}{-3.411644} \\
\hline & & & $\% 10$ & -2.567337 & \multicolumn{2}{|l|}{-3.127696} \\
\hline
\end{tabular}

Tablo 2: Gecikme Uzunluğu Tablosu

\begin{tabular}{ccccccc}
\hline Lag & LogL & LB & FPE & AIC & SC & HQ \\
\hline 0 & -134746.4 & NA & $2.64 \mathrm{e} 39+$ & 110.6350 & 110.6516 & 110.6410 \\
1 & -95076.96 & 79078.33 & $1.97 \mathrm{e} 25+$ & 78.10588 & 78.23917 & 78.15433 \\
2 & -94778.34 & 593.5593 & $1.60 \mathrm{e} 25+$ & 77.90094 & $78.15086^{*}$ & $77.99179^{*}$ \\
3 & -94720.30 & 115.0329 & $1.59 \mathrm{e} 25+$ & 77.89351 & 78.26006 & 78.02676 \\
4 & -94667.77 & 103.8115 & $1.59 \mathrm{e} 25+^{*}$ & $77.89062^{*}$ & 78.37379 & 78.06626 \\
5 & -94631.30 & 71.86509 & $1.60 \mathrm{e} 25+$ & 77.90090 & 78.50071 & 78.11895 \\
6 & -94604.86 & 51.93790 & $1.63 \mathrm{e} 25+$ & 77.91943 & 78.63586 & 78.17987 \\
7 & -94571.55 & 65.25170 & $1.65 \mathrm{e} 25+$ & 77.93231 & 78.76537 & 78.23515 \\
8 & -94534.53 & 72.31609 & $1.67 \mathrm{e} 25+$ & 77.94214 & 78.89183 & 78.28738 \\
9 & -94511.46 & 44.92294 & $1.71 \mathrm{e} 25+$ & 77.96343 & 79.02975 & 78.35107 \\
10 & -94470.48 & 79.56923 & $1.72 \mathrm{e} 25+$ & 77.97002 & 79.15297 & 78.40005 \\
11 & -94441.91 & 55.30543 & $1.75 \mathrm{e} 25+$ & 77.98679 & 79.28637 & 78.45922 \\
12 & -94404.70 & $71.83942^{*}$ & $1.76 \mathrm{e} 25+$ & 77.99647 & 79.41267 & 78.51129 \\
\hline
\end{tabular}

Gecikme uzunluğunun tespitinden sonra Çok değişkenli VAR (2) EGARCH $(1,1)$ modeli tahmin edilmiş tablo 3 ve tablo 4'te sunulmuştur. 


\begin{tabular}{|c|c|c|c|c|c|c|c|c|c|}
\hline \multirow{16}{*}{ 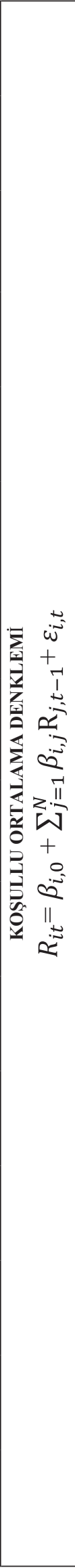 } & $c^{\text {F }}$ & 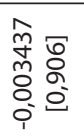 & 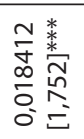 & 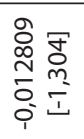 & 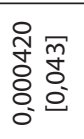 & 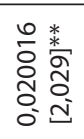 & 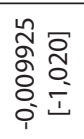 & 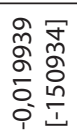 & \multirow{16}{*}{ 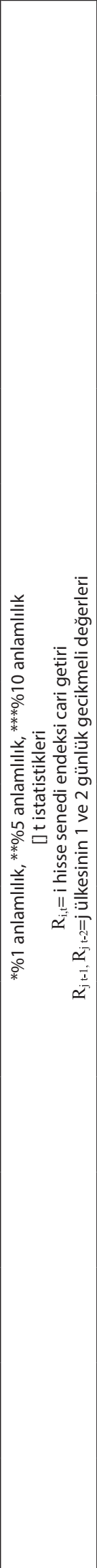 } \\
\hline & $\alpha^{\ldots}$ & 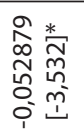 & 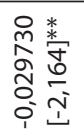 & 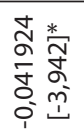 & 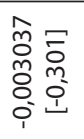 & 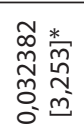 & 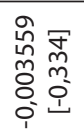 & 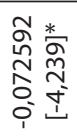 & \\
\hline & $x^{\frac{7}{5}}$ & 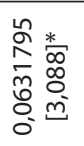 & 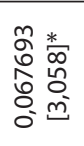 & 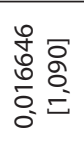 & 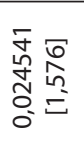 & 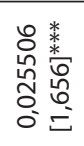 & 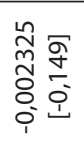 & 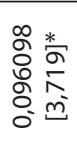 & \\
\hline & $x^{\bar{t}}$ & 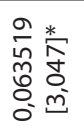 & 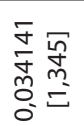 & 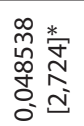 & 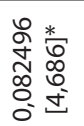 & 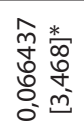 & 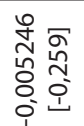 & 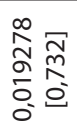 & \\
\hline & $x^{\frac{7}{n+n}}$ & 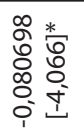 & 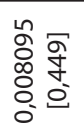 & 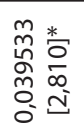 & 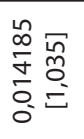 & 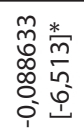 & 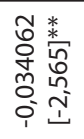 & 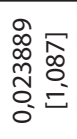 & \\
\hline & $\alpha^{x^{n}}$ & 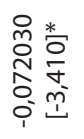 & 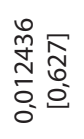 & 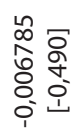 & 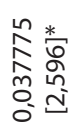 & 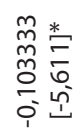 & 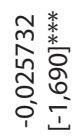 & 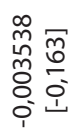 & \\
\hline & $c^{\frac{7}{5}}$ & 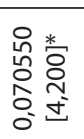 & 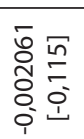 & 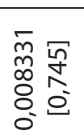 & 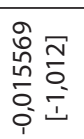 & 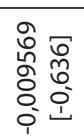 & 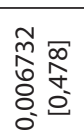 & 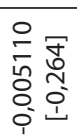 & \\
\hline & $\propto^{\frac{5}{+}}$ & 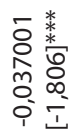 & 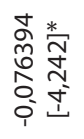 & 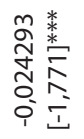 & 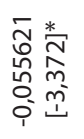 & 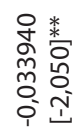 & 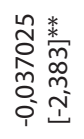 & 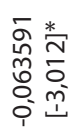 & \\
\hline & $c^{\frac{2}{m^{n}}}$ & 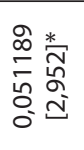 & 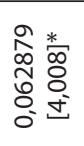 & 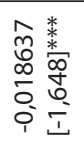 & 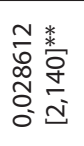 & 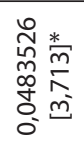 & 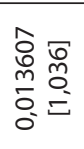 & 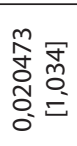 & \\
\hline & $c^{\overline{w^{5}}}$ & 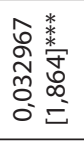 & 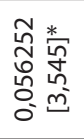 & 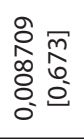 & 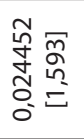 & 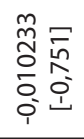 & 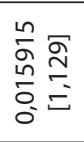 & 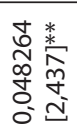 & \\
\hline & $x^{\frac{7}{v}}$ & 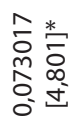 & $\begin{array}{l} \\
0 \\
0 \\
0 \\
0 \\
0 \\
0 \\
0 \\
0 \\
0\end{array}$ & 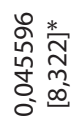 & 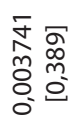 & 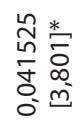 & 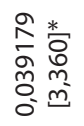 & 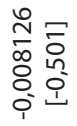 & \\
\hline & $x^{\bar{v}}$ & 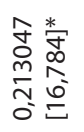 & 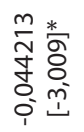 & 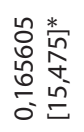 & 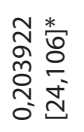 & 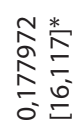 & 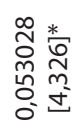 & 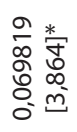 & \\
\hline & $\alpha^{2}$ & 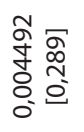 & 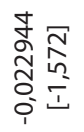 & 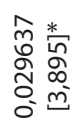 & 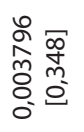 & 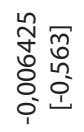 & 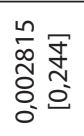 & 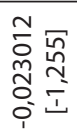 & \\
\hline & $x^{ \pm}$ & 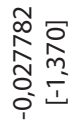 & 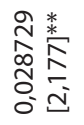 & 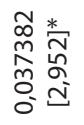 & 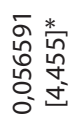 & 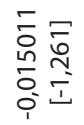 & 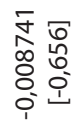 & 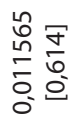 & \\
\hline & $a^{0}$ & 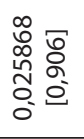 & 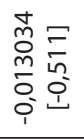 & 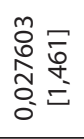 & 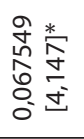 & 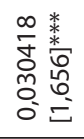 & 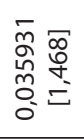 & 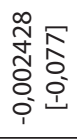 & \\
\hline & & $\frac{8}{\frac{0}{2}}$ & 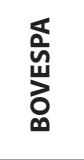 & 忌 & 岁 & 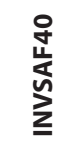 & ㅇํㅇ & $\underset{\substack{\mathrm{u} \\
\stackrel{口}{\infty}}}{\mathfrak{s}}$ & \\
\hline
\end{tabular}




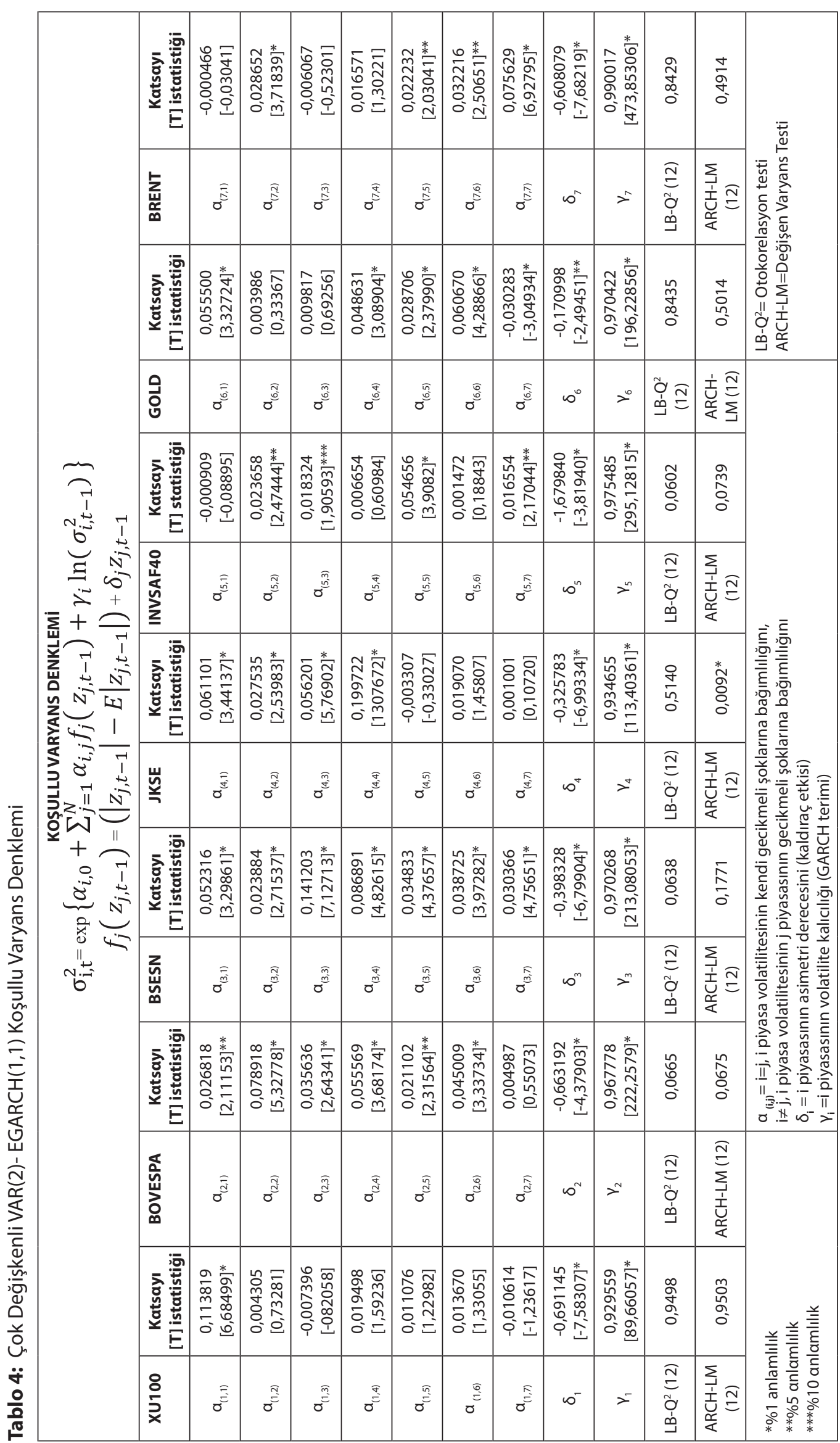


Koşullu varyans, geçmiş bilgilerin ve geçmiş koşullu varyansın bir fonksiyonudur. $\alpha_{\mathrm{i}, \mathrm{i}}$ ve $\Upsilon_{\mathrm{i}}$ katsayıları istatistiksel olarak anlamlıdır. Mevcut volatilite üzerinde geçmiş bilgilerin asimetrik veya kaldıraç etkisi, volatilite etkileşimleri karşısında seçilen piyasalarda piyasaların asimetrik olabileceği fikrine destek veren önemli bir göstergedir. Asimetrinin derecesi, $\delta_{i}$ katsayılarının tahmin edilmesi temeline dayanmakta model incelendiği zaman da $\delta_{i}$ katsayısı INVSAF40'da oldukça yüksek olduğu görülmektedir. Volatilite kalıcılığı $\Upsilon_{i}$ ile ölçülmüş ve tüm değişkenler için yüksek ve bire çok yakın olmakla birlikte volatilite kalıcılığı en düşük endeks XU100 hisse senedi endeksidir. Bu sonuç piyasaya ulaşan yeni bilginin piyasada ortaya çıkardığı oynaklığın XU100 endeksinde diğer endekslere göre kalıcılığının daha düşük olduğu şeklinde yorumlanmıştır.

Kıymetli madenlerle gelişmekte olan 5 ülke hisse senedi endeksi arasındaki getiri yayılımını temsil eden tablo 3 sonuçları incelendiğinde, altın piyasalarının geçmiş getirilerinden XU100 ve BSESN hisse senedi endeksine doğru pozitif ve tek yönlü bir getiri yayılımı olduğu $R_{\mathrm{j}, \mathrm{t}-1}$ ve $\mathrm{R}_{\mathrm{j}, \mathrm{t}-2}$ katsayılarından anlaşılmaktadır. Altın piyasası getirileri ile BOVESPA, JKSE ve INVSAF40 endeksleri arasında karşıııkı getiri yayılımının olduğu ayrıca kanıtlanmıştır.

BRENT petrol getirilerinden ise JKSE dışındaki bütün hisse senedi piyasalarına negatif yönlü bir getiri yayılımı olduğu, BOVESPA ve BSESN hisse senedi endeksleri ile getiri yayılımının karşılıklı olduğu tespit edilmiştir.

5 gelişmekte olan ülke borsa endeksleri arasındaki getiri yayılımına ilişkin araştırma sonuçları incelendiğinde tüm hisse senedi endekslerinin geçmiş getirilerinden diğer piyasalara karşılıklı getiri yayılımı olduğu anlaşılmaktadır. Özellikle makroekonomik olarak birbiriyle benzer nitelikteki söz konusu ülkelerde tablo 3'den çıkan en önemli sonuç piyasa etkinliği açısından hiçbir hisse senedi endeksinin birbirine bilgi etkinliği açısından üstünlüğünün olmadığıdır.

Kıymetli madenlere ait koşullu varyans denklemini gösteren tablo 4 sonuçları incelendiğinde Altın piyasalarından BOVESPA, BSESN endeksine doğru pozitif yönlü volatilite yayılımı olduğu ve BRENT piyasaları ile Altın piyasalarının karşılıklı volatilite yayılımının olduğu tespit edilmiştir.

BRENT petrol piyasasından BSESN endeksine doğru pozitif yönlü volatilite yayılımı olduğu INVSAF40 ve
Altın piyasaları ile karşııkı volatilite yayılımı olduğu belirlenmiştir.

5 gelişmekte olan ülke borsa endeksleri arasındaki volatilite yayılımına ilişkin araştırma sonuçları incelendiğinde çıkan en önemli sonuç XU100 endeksinin kendi geçmiş şokları hariç diğer endekslerden etkilenmediği dolayısıyla diğer piyasalara göre daha güçlü bir yapıya sahip olduğudur.

Her bir piyasada koşullu ortalamayı tanımlayan parametrelere odaklanıldığında birkaç tane çok yönlü öncül/ardıl (lead/lag) ilişki görülebilir. Modelden elde edilen artıklar incelendiğinde herhangi bir otokorelasyon sorunu olmadığı ve artıkların JKSE endeksi hariç diğer endeksler için sabit varyansa sahip olduğu test sonuçlarından anlaşılmaktadır.

Hem getiri hem de volatilite yayımlarının çok yönlü olması aynı makro ekonomik özelliklere sahip piyasaları arasında hiçbir piyasanın bilgi açısından diğer piyasalara nazaran ana rol üstlenmediğini desteklemektedir. En önemli soru bu ilişkilerin ne ölçüde kullanılarak anormal karlar edilebileceği ve bu ilişkilerin ekonomik açıdan öneminin ne olduğudur. Bu soruların cevaplanabilmesi için fiyat işlemlerine ilişkin detaylı bilginin yanı sıra kur riskinin de ölçülmesine ihtiyaç vardır.

Bu bulgular bilginin işaretinin ve büyüklüğünün volatilite geçiş mekanizmasının önemli bir belirleyicisi olduğunu göstermektedir. Bir piyasadaki kötü haberlerin volatilite artışını pozitif haberlerden daha çok etkilediği $a_{i, j}$ ve $\delta_{j}$ katsayıları kullanılarak belirlenebilir.

\section{SONUÇ}

Son yıllarda hisse senedi piyasalarının hayal kırıklığı yaratan performansı ve hisse senedi piyasaları ile emtia piyasaları arasındaki düşük korelasyondan dolayı emtia piyasaları yatırımcılar tarafından tercih edilmektedir. Bu yüzden emtia piyasalarındaki kırılganlık oldukça artmaktadır. Altın ve petrol gibi kıymetli maden piyasalarının yükselen trendi uluslararası finansal piyasaların artan volatilitesiyle birlikte emtia ve piyasa volatilitesinin incelenmesini gerekli kılmaktadır. Bu çalışmada gelişmekte olan ülkelerin borsaları ve kıymetli madenler arasındaki getiri ve volatilite yayılımı çok değişkenli VAR-EGARCH modeli ile incelenmiştir. Yapılan analiz sonucunda;

Volatilite geçiş mekanizmasında negatif haberlerin volatilite üzerinde büyük etkisinin olduğu negatif haberlerin pozitif haberlerden daha çok volatiliteyi artırdığı görülmektedir. Piyasalar arasında karşılıklı ilişki- 
lerin olduğu analiz sonuçlarında ayrıca gözlenmiştir. Tüm hisse senedi endekslerinin geçmiş getirilerinden diğer piyasalara karşılıklı getiri yayılımı olduğu anlaşılmaktadır. Özellikle makroekonomik olarak birbiriyle benzer nitelikteki söz konusu ülkelerde piyasa etkinliği açısından hiçbir hisse senedi endeksinin birbirine bilgi etkinliği açısından üstünlüğünün olmadığı ortaya konmuştur. 5 gelişmekte olan ülke borsa endeksleri arasındaki volatilite yayılımına ilişkin araştırma sonuçları incelendiğinde çıkan en önemli sonuç XU100 endeksinin kendi geçmiş şokları hariç diğer endekslerden etkilenmediği dolayısıyla diğer piyasalara göre daha güçlü bir yapıya sahip olduğudur. Buradan ha- reketle Türkiye piyasasının kıymetli madenlerin fiyat hareketlerinden etkilenmediği dolayısıyla yatırımcılar için güvenli bir liman olabileceği söylenebilmektedir. Ayrıca bu çalışmanın ilerde kriz dönemlerini de dikkate alan daha kapsamlı çalışmaların yapılabilmesi için temel olacağı da düşünülmektedir.

Elde edilen sonuçlar Hammoudeha ve Choi (2007), Bhar ve Nikolova (2010), Sari vd. (2010), Palakkod (2012), Chang vd. (2013), Ewing ve Malik (2013), Hossenidoust vd. (2013), Mensi vd. (2013), Sattory vd. (2014), Uludağ ve Lkhamazhapov (2014), Sadorsky (2014), Arouri vd. (2015), Mensi vd. (2015), Boubaker ve Raza (2017) çalışmalarını destekler niteliktedir.

\section{KAYNAKLAR}

Arouri, M., Lahiani, A. ve Nguyen, D. (2015) “World Gold Prices and Stock Returns in China: Insights for Hedging and Diversification Strategies", Economic Modelling, 44: 273-282.

Bhar, R. ve Nikolova, B. (2010) "Global Oil Prices, Oil Industry and Equity Returns: Russian Experience", Scottish Journal of Political Economy, 57(2): 169-186.

Batten, J. A., Ciner, C. ve Lucey, B.M. (2015) "Which Precious Metals Spill Over On Which, When And Why? Some Evidence", Applied Economics Letters, 22: 466-473.

Basher, S. A. ve Sadorsky, P. (2016) “Hedging Emerging Market Stock Prices with Oil, Gold, VIX, and Bonds: A Comparison Between DCC, ADCC and GO-GARCH", Energy Economics, 54: 235-247.

Bollerslev, T. (1986) "Generalized Autoregressive Conditional Heteroskedasticity", Journal of Econometrics, 31(3): 307-327.

Bouri, E., Molnar, P., Azzi, G., Roubaud, D. ve Hagfors, L. I. (2017) "On the Hedge and Safe Haven Properties of Bitcoin: Is it Really More than Diversifier?", Finance Research Letters, 20: 192-198.

Boubaker, H. ve Raza, S. A. (2017) "A Wavelet Analysis of Mean and Volatility Spillovers Between Oil and BRICS Stock Markets", Energy Economics, 64: 105-117.

Brooks, C. ve Prokopczuky, M. (2013) "The Dynamics of Commodity Prices", Quantitative Finance, 13(4): 1-44.

Büyükşahin, B., Haigh, M. S. ve Robe, M. A. (2008) "Commodities and Equities: A Market of One ?", The Economist, 1-47.

Chang, C. L., McAleer, M. ve Tansuchat, R. (2013) "Conditional Correlations and Volatility Spillovers Between Crude Oil and Stock Index Returns", The North American Journal of Economics and Finance, 25, 116-138.
Ciner, C. (2013) "Oil and Stock Returns: Frequency Domain Evidence", Journal of International Financial Markets, Institutions \& Money, 23: 1-11.

Çevik, E. İ. ve Pekkaya, M. (2007) "Spot Ve Vadeli İşlem Fiyatlarının Varyansları Arasındaki Nedensellik Testi", Dokuz Eylül Üniversitesi I'ktisadi ve İdari Bilimler Fakültesi Dergisi, 22(2): 49-66.

Dickey, D. A. ve Fuller, W. A. (1979), Distribution Of The Estimators For Autoregressive Time Series With A Unit Root. Journal of The American Statistical Association, 74: 427-431.

Dickey, D. A. ve Fuller, W. A. (1981) "Likelihood Ratio Satatistics for Autoregressive Time Series with a Unit Root", Econometrica, 49(4): 1057-1072.

Engle, R. F. (1982) "Autoregressive Conditional Heteroscedasticity with Estimates of the Variance of United", Econometrica, 50(4): 987-1007.

Engle, R. F. ve Ng, V. K. (1993) "Measuring and Testing The Impact Of News On Volatility" The Journal of Finance, 48(5), 1749-1778.

Ewing, B.T. ve Malik, F. (2013) "Volatility Transmission Between Gold and Oil Futures Under Structural Breaks", International Review of Economics and Finance, 25,: 113121.

Gokmenoglu, K. K. ve Fazlollahi, N. (2015) "The Interactions among Gold, Oil, and Stock Market: Evidence From S\&P 500", Procedia Economics and Finance, 25: 478-488.

Granger C.W.J. ve Newbold P. (1974) "Spurious Regressions In Economics", Journal of Econometrics, 2: 111-120.

Gujarati, D. N. ve Porter, D.C. (2012) “Temel Ekonometri”, 1. Baskı, (5. Baskıdan Çeviri Ümit Şenesen ve Gülay Günlük Şenesen), İstanbul, Literatür Yayıncılık. 
Hammoudeha, S. ve Choi, K. (2007) "Characteristics of Permanent and Transitory Returns in Oil-Sensitive Emerging Stock Markets: The Case of GCC Countries", International Financial Markets, Institutions And Money, 17: 231-245.

Hossenidoust, E., Janor, H., Yusefi, M. ve Majid, H. A. (2013) "Volatility Spillovers Across Commodity and Stock Markets Among ASEAN Countries", Prosiding Perkem VIII, JILID 3, 1401-1412.

Kaltalıoğlu, M. ve Soytaş, U. (2011) "Volatility Spillover from Oil to Food and Agricultural Raw Material Markets", Modern Economy, 2: 71-76.

Koutmos, G. (1996) "Modeling the Dynamic Interdependence of Major European Stock Markets", Journal of Business Finance \& Accounting, 23(7): 975-988.

Koutmos, G. ve Booth, G. (1995) "Asymmetric Volatility Transmission in International Stock Markets", Journal of International Money and Finance, 14: 747-762.

MacKinnon, J. G. (1991) "Critical Values for Cointegration Tests", R. F. Engle and C. W. J. Granger (eds), Long-run Economic Relationships: Readings in Cointegration içerisinde, Ch. 13, pp. 267-76, Oxford: Oxford University Press.

Mensi, W., Beljid, M., Boubaker, A. ve Managi, S. (2013) "Correlations and Volatility Spillovers Across Commodity and Stock Markets: Linking Energies, Food and Gold", Economic Modelling, 32: 15-22.

Mensi, W., Hammoudeh, Shawkat, ve Kang, H. S. (2015) "Precious Metals, Cereal, Oil And Stock Market Linkages And Portfolio Risk Management: Evidence from Saudi Arabia", Economic Modelling, 51: 340-358.
Nelson, D. (1991) "Conditional Heteroskedasticity in Asset Returns: A New Approach", Econometrica, 59(2): 347-370.

Palakkod, S. (2012) "Integration of Capital, Commodity and Currency Markets: A Study on Volatility Spillover", The Romanian Economic Journal, Year 15, 44: 87-100.

Phillips, P.C. ve Perron, P. (1988) "Testing for Unit Roots in Time Series Regression", Biometrika, 75: 335-346.

Sari, R., Hammoudeh, S., ve Soytas, U. (2010) “Dynamics Of Oil Price, Precious Metal Prices, And Exchange Rate", Energy Economics, 32: 351-362.

Sadorsky, P. (2014) "Modeling Volatility and Correlations Between Emerging Market Stock PRices and the Prices of Copper, Oil and Wheat", Energy Economics, 43: 72-81. Sattary, A., Temurlenk, M. S., Bilgiç, A. ve Çelik, A. K. (2014) "Volatility Spillovers Between World Oil Market and Sectors of BIST", AsianSocial Science, 19(8): 156-164.

Soytas, U., Sari, R., Hammoudeh, S. ve Hacihasanoglu, E. (2009) "The Oil Prices, Precious Metal Prices And Macroeconomy In Turkey", Energy Policy, 37: 5557-5566.

Tsay, R. S. (2002) "Analysis of Financial Time Series", United State of America, John Wiley \& Sons.

Tarı, R. (2010) “Ekonometri”, Kocaeli, Umuttepe Yayınları.

Uludag, B. K., ve Lkhamazhapov, Z. (2014)"Long Memory And Structural Breaks In The Returns And Volatility Of Gold: Evidence From Turkey", Applied Economics, 46(31): 3777- 3787.

Yavuz, Ç. N. ( 2015) “Finansal Ekonometri”, İstanbul, Der Yayınları. 